\title{
The nitrogen effect of peat addition in clay soil
}

\author{
MARTti SALONEN ${ }^{1}$ ) and Jorma KäHÄRI \\ Agricultural Research Centre, Department of Agricultural Chemistry and Physics, \\ SF-01300 Vantaa 30
}

\begin{abstract}
The nitrogen effect of ligno Carex peat addition to heavy clay with a low content of organic matter was investigated in a pot experiment of eight years. The test plant was oats. The nitrogen effect proved to be very small. It was evident that the positive effect of an addition of peat to mineral soil, which in some cases can be very marked in field conditions, is mainly physical. Primarily it may be due to improved soil moisture conditions.
\end{abstract}

\section{Introduction}

It is common knowledge that the addition of suitable organic matter may promote plant growth especially in soil with a low humus content. The most valuable of these humus fertilizers is farmyard manure, which contains plant nutrients as well as organic matter. It has not been clearly defined to what extent the plant growth promoting effect of farmyard manure is dependent on organic matter or on plant nutrients.

Since the amount of farmyard manure is usually insufficient other organic matters have been used instead. In Finnish conditions well humified peat has been used as a humus fertilizer (TuORILA 1945, 1946; Pessi and PAUlamäki 1964). Its usage has given more limited and more varying results than those obtained with farmyard manure (cf. Allison 1973, p. 614).

Not even the best peat can be compared with farmyard manure in regard to qualities other than the organic matter and total nitrogen contents. But the effect of these factors seprately has not been clearly defined. We have not succeeded in finding in the literature exact facts on the nature of the effect of humus addition, which would have been based on experimental results. It is almost impossible to separate the physical effect and the possible plant nutrient effect of humus fertilizing in field experiments. On the other hand, in a pot experiment it is possible to obtain reasonably precise knowledge of the plant nutrient effect because in an open air pot experiment the water supply can be arranged near to optimum.

1) retired. 


\section{The arrangement of the experiment}

In order to get experimental results concerning the nitrogen effect of peat, a pot experiment was started in autumn 1964. The pots were usual 5-litre Mitscherlich pots. The experimental soil was taken from subsoil of very heavy clay near Helsinki. The soil came from a depth of $30-60 \mathrm{~cm}$ and its humus content was very low. The soil had been taken already in the previous autumn and it had been kept wet and subjected to the influence of frost so that it was properly aggregated when the experiment was started. The peat used as humus fertilizer originated from the Leteensuo Experimental Station in southern Finland. The peat was taken from a virgin fen and it was well-humified ligno Carex peat. According to a previous study, the nitrogen of peat sampled almost from the same place mineralized well (SALONEN 1940). Some of the properties of the soils used in the experiment were as follows:

\begin{tabular}{|c|c|c|c|c|c|c|c|c|c|}
\hline & \multirow{2}{*}{$\begin{array}{c}\text { Vol. } \\
\text { weight }\end{array}$} & \multirow{2}{*}{$\begin{array}{c}\text { Loss } \\
\text { of ign. } \\
\%\end{array}$} & \multirow{2}{*}{$\begin{array}{c}\text { Tot. N } \\
\%\end{array}$} & \multirow{2}{*}{$\mathrm{C} / \mathrm{N}$} & \multirow{2}{*}{$\begin{array}{c}\mathrm{pH} \\
\mathrm{H}_{2} \mathrm{O}\end{array}$} & \multirow{2}{*}{$\begin{array}{l}\text { Nutr. } \\
\text { amm. }\end{array}$} & \multirow{2}{*}{$\begin{array}{c}\begin{array}{c}\text { extracted } \\
\text { acetate }\end{array} \\
\mathbf{K}\end{array}$} & \multicolumn{2}{|c|}{$\begin{array}{l}\text { by acid } \\
\mathrm{mg} / 1 \text { soil }\end{array}$} \\
\hline & & & & & & & & $\mathrm{Ca}$ & $\mathrm{Mg}$ \\
\hline $\begin{array}{l}\text { Heavy clay } \\
\text { Ligno Carex }\end{array}$ & 1.23 & 3.23 & - & - & 6.9 & 1.5 & 390 & 2520 & 1220 \\
\hline peat & 0.46 & 75.0 & 2.71 & 14.7 & 4.2 & 2.5 & 69 & 1860 & 23 \\
\hline
\end{tabular}

The pots were filled with different soils as follows:

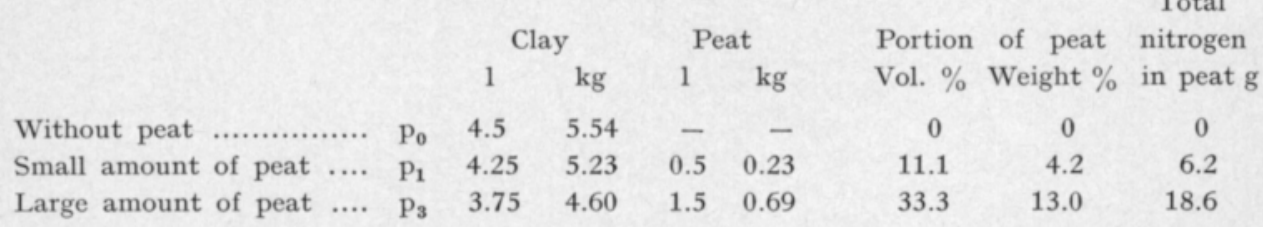

Suitable amounts of other nutrients except nitrogen were given yearly to every pot (cf. KäнÄRI 1976). One half of the pots received annually no nitrogen fertilization $\left(\mathrm{N}_{0}\right)$ while the other half was given annually nitrogen $2 \mathrm{~g} /$ pot $\left(\mathrm{N}_{2}\right)$ as ammonium nitrate.

Half of the pots were kept outdoors during the whole year (o), the other half was indoors in room temperature $(18-20)$ during winter time (i). The soil in the pots was kept wet all the time. The treatments for both halves were as follows:

$\begin{array}{lcccccc} & \mathrm{p}_{0} \mathrm{~N}_{0} & \mathrm{p}_{1} \mathrm{~N}_{0} & \mathrm{p}_{3} \mathrm{~N}_{0} & \mathrm{p}_{0} \mathrm{~N}_{2} & \mathrm{p}_{1} \mathrm{~N}_{2} & \mathrm{p}_{3} \mathrm{~N}_{2} \\ \text { Peat, 1 } & 0 & 0.5 & 1.5 & 0 & 0.5 & 1.5 \\ \text { Nitrogen, } \mathrm{g} & 0 & 0 & 0 & 2 & 2 & 2\end{array}$

The test plant used every year was Pendek oats, harvested when ripe.

\section{Changes in soil chemical properties}

In long term pot experiments, where high and different amounts of fertilizers are used, there is a certain risk that in some pots the state of the soil may change so as to disturb the growth. In order to follow the changes in the soil $\mathrm{pH}$ and electrical conductivity, measurements were made each autumn after the harvest (Table 1 and Figures 1 and 2). According to these results all the 
$\mathrm{N}_{2}$-pots were limed with $12 \mathrm{~g}$ of calcium carbonate in spring 1971 . On the basis of yield analyses, an additional potassium fertilization of $415 \mathrm{mg} \mathrm{K}$ to $\mathrm{N}_{0}$-pots and $1660 \mathrm{mg} \mathrm{K}$ to $\mathrm{N}_{2}$-pots was applied in spring 1971 .

Table 1. The means of the annually measured $\mathrm{pH}$ and electrical conductivities.

\begin{tabular}{|c|c|c|c|c|c|c|c|c|c|c|}
\hline & \multicolumn{4}{|c|}{ Winter storage } & \multicolumn{6}{|c|}{ Peat addition } \\
\hline & \multicolumn{2}{|c|}{$\mathrm{N}_{0}$} & \multicolumn{2}{|c|}{$\mathrm{N}_{2}$} & \multicolumn{3}{|c|}{$\mathrm{N}_{0}$} & \multicolumn{3}{|c|}{$\mathrm{N}_{2}$} \\
\hline & o & i & o & $\mathrm{i}$ & $\mathrm{p}_{0}$ & $\mathrm{p}_{1}$ & $\mathrm{P}_{3}$ & $\mathrm{p}_{0}$ & $\mathrm{p}_{1}$ & $\mathrm{P}_{3}$ \\
\hline $\mathrm{pH}_{\mathrm{H} 2} 0$ & 5.4 & 5.3 & 5.2 & 5.3 & 5.6 & 5.4 & 5.1 & 5.5 & 5.3 & 5.0 \\
\hline $\mathrm{pH}_{\mathrm{KCl}}$ & 4.5 & 4.7 & 4.5 & 4.4 & 4.7 & 4.7 & 4.5 & 4.6 & 4.4 & 4.3 \\
\hline $\begin{array}{l}\text { Elect. cond. } \\
10 x m m h o\end{array}$ & 7.2 & 9.2 & 6.8 & 4.1 & 7.1 & 8.9 & 8.8 & 6.4 & 5.0 & 5.0 \\
\hline
\end{tabular}

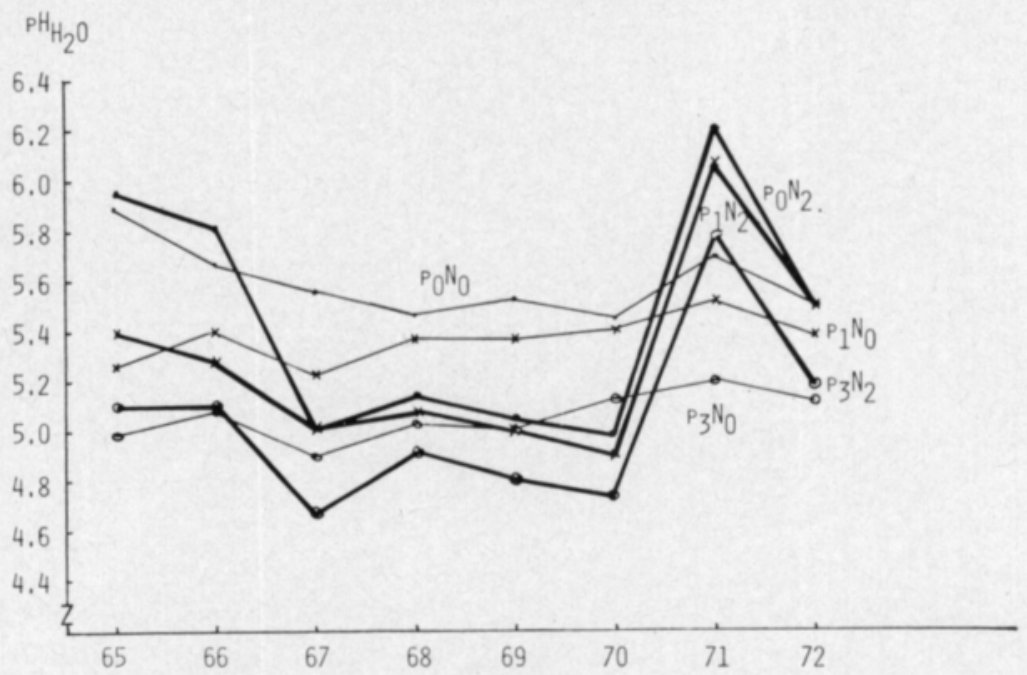

Figure 1. pH-values from different years.

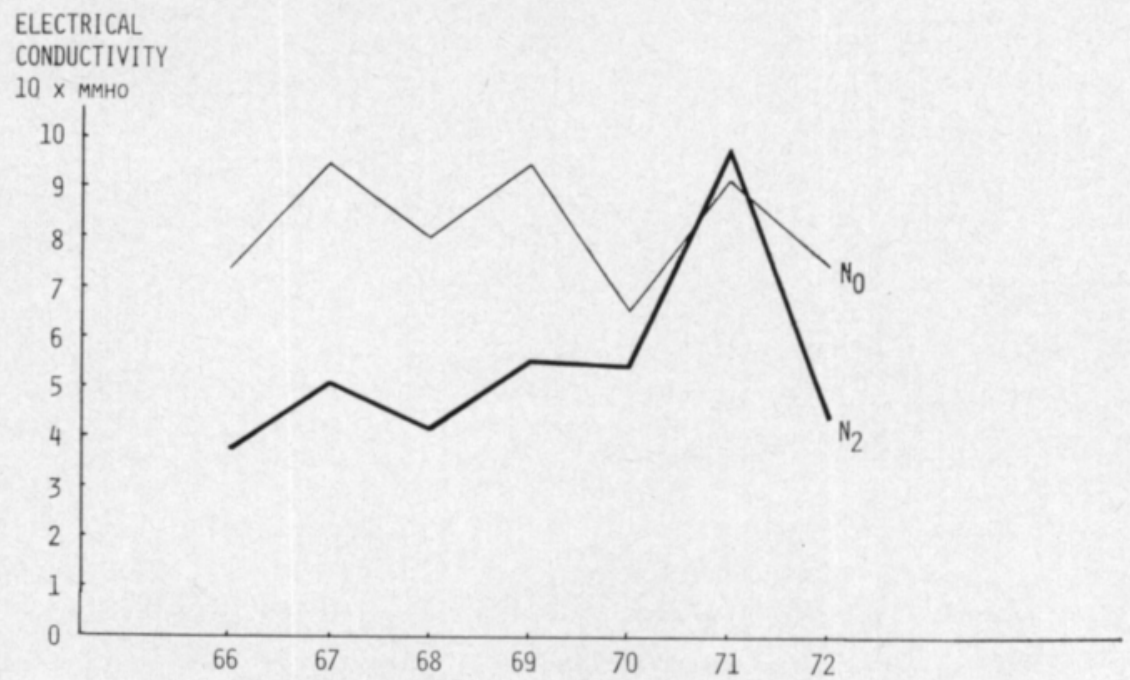

Figure 2. Electrical conductivities of soil suspensions from different years. 
Table 2. The results of soil analyses at the end of the experiment 1972, mg/l.

\begin{tabular}{|c|c|c|c|c|c|c|c|c|c|c|c|}
\hline & & \multicolumn{4}{|c|}{ Winter storage } & \multicolumn{6}{|c|}{ Peat addition } \\
\hline & & \multicolumn{2}{|c|}{$\mathrm{N}_{0}$} & \multicolumn{2}{|c|}{$\mathrm{N}_{2}$} & \multicolumn{3}{|c|}{$\mathrm{N}_{0}$} & \multicolumn{3}{|c|}{$\mathrm{N}_{2}$} \\
\hline & & 0 & $\mathrm{i}$ & 0 & $\mathrm{i}$ & $\mathrm{P}_{0}$ & $\mathrm{p}_{1}$ & $\mathrm{p}_{3}$ & $\mathrm{p}_{0}$ & $\mathrm{p}_{1}$ & $\mathrm{P}_{3}$ \\
\hline $\mathbf{P}$ & ............. & 52 & 52 & 11 & 11 & 57 & 49 & 51 & 10 & 9 & 13 \\
\hline $\mathbf{K}$ & ............ & 343 & 510 & 153 & 157 & 415 & 505 & 360 & 170 & 145 & 150 \\
\hline $\mathrm{Ca}$ & .............. & 2833 & 2617 & 3867 & 3967 & 2750 & 2750 & 2675 & 4100 & 3900 & 3750 \\
\hline $\mathrm{Mg}$ & ............. & 873 & 707 & 590 & 584 & 855 & 847 & 742 & 665 & 598 & 497 \\
\hline
\end{tabular}

At the end of the experiment, in autumn 1972, the soils were analysed in accordance with the soil testing method used in Finland (KURKI et al 1965).

The results are presented in Table 2. The results of soil analyses show no changes that might disturb plant growth.

\section{Yield results}

The yield results from the different years are presented in Table 3. The yields from the first year differ clearly from the others. In the first year the yields were relatively good even without nitrogen fertilization. This phenomenon is due to the sfallow effect" and may take place when ground soil is allowed

Table 3. Annual dry-matter yields of oats $\mathrm{g} / \mathrm{pot}$.

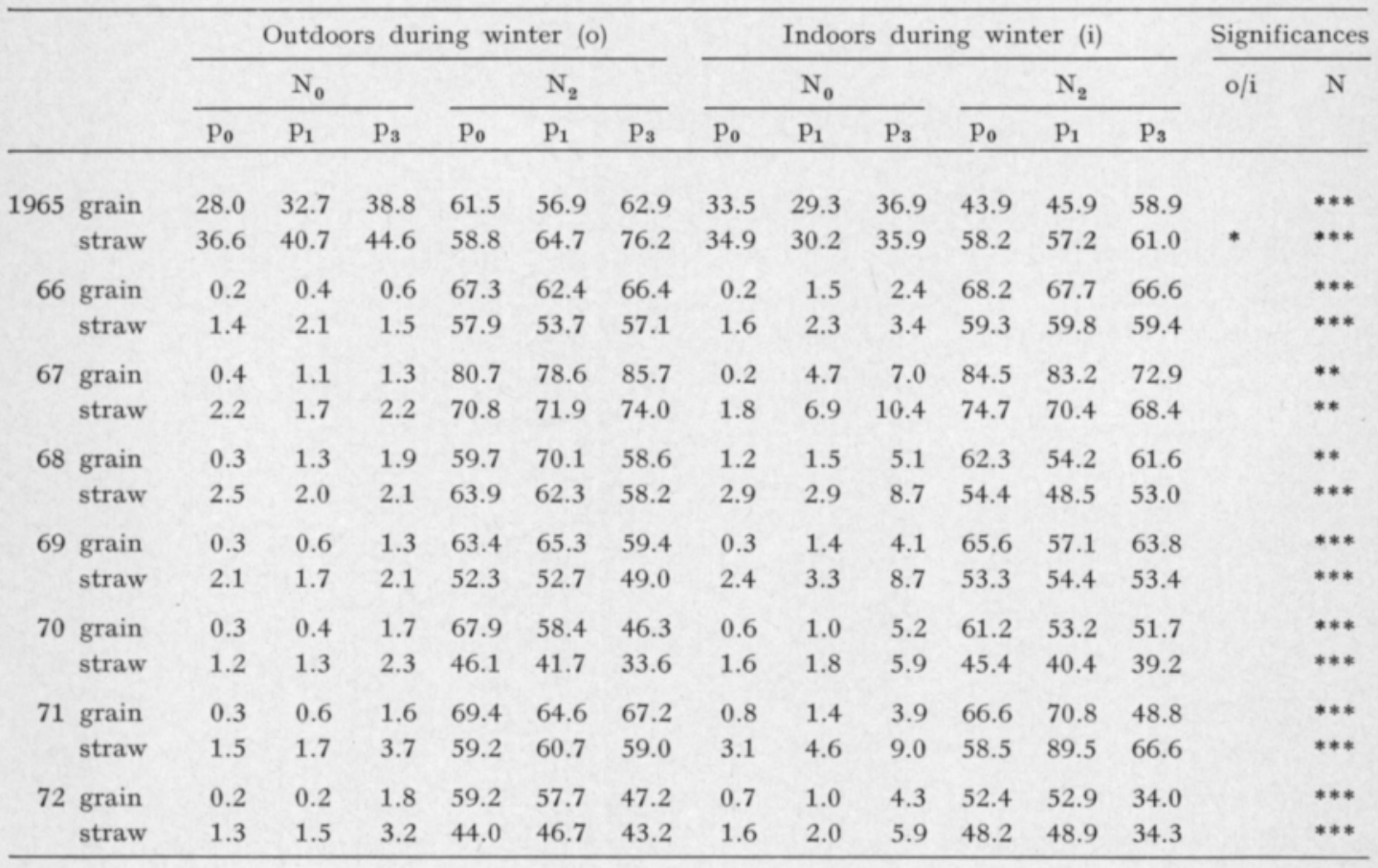


Table 4. Means of the yields from the years 1966-72, g/pot.

\begin{tabular}{|c|c|c|c|c|c|c|c|c|c|c|c|}
\hline & \multicolumn{4}{|c|}{ Winter storage } & \multicolumn{6}{|c|}{ Peat addition } & \multirow{3}{*}{$\begin{array}{r}\text { Sign. } \\
\mathrm{N}\end{array}$} \\
\hline & \multicolumn{2}{|c|}{$\mathrm{N}_{0}$} & \multicolumn{2}{|c|}{$\mathrm{N}_{2}$} & \multicolumn{3}{|c|}{$\mathrm{N}_{0}$} & \multicolumn{3}{|c|}{$\mathrm{N}_{2}$} & \\
\hline & o & $\mathrm{i}$ & 0 & $\mathrm{i}$ & $\mathrm{P}_{0}$ & $\mathrm{p}_{1}$ & $\mathrm{p}_{3}$ & $\mathrm{P}_{0}$ & $\mathrm{p}_{1}$ & $\mathrm{P}_{3}$ & \\
\hline Grain & 0.8 & 2.3 & 64.3 & 61.9 & 0.4 & 1.2 & 3.0 & 66.0 & 64.0 & 59.3 & $* * *$ \\
\hline Straw & 2.0 & 4.3 & 55.1 & 56.2 & 1.9 & 2.6 & 4.9 & 56.3 & 57.2 & 53.4 & *** \\
\hline Total & 2.8 & 6.6 & 119.4 & 118.1 & 2.3 & 3.8 & 7.9 & 122.3 & 121.2 & 112.7 & $* * *$ \\
\hline
\end{tabular}

Table 5. Plant nutrient contents of yields. The means of nitrogen are from the years 196672, others from the years 1965-69.

\begin{tabular}{|c|c|c|c|c|c|c|c|c|c|c|c|}
\hline & \multicolumn{4}{|c|}{ Winter storage } & \multicolumn{6}{|c|}{ Peat addition } & \multirow{3}{*}{$\begin{array}{r}\text { Sign. } \\
\mathrm{N}\end{array}$} \\
\hline & \multicolumn{2}{|c|}{$\mathrm{N}_{0}$} & \multicolumn{2}{|c|}{$\mathrm{N}_{2}$} & \multicolumn{3}{|c|}{$\mathrm{N}_{0}$} & \multicolumn{3}{|c|}{$\mathrm{N}_{2}$} & \\
\hline & 0 & $\mathrm{i}$ & o & $\mathrm{i}$ & $\mathrm{P}_{0}$ & $\mathrm{p}_{1}$ & $\mathrm{p}_{3}$ & $\mathrm{p}_{0}$ & $\mathrm{p}_{1}$ & $\mathrm{P}_{3}$ & \\
\hline \multicolumn{12}{|c|}{ Grain, $\mathrm{g} / \mathrm{kg}$} \\
\hline $\mathrm{N}$ & 18.5 & 15.8 & 20.4 & 21.6 & 20.3 & 16.3 & 14.9 & 20.3 & 21.0 & 21.8 & $* * *$ \\
\hline $\mathbf{P}$ & 3.8 & 3.4 & 2.9 & 3.0 & 3.7 & 3.5 & 3.7 & 3.0 & 3.6 & 2.9 & \\
\hline K & 3.5 & 4.0 & 4.1 & 4.1 & 4.7 & 3.5 & 3.7 & 4.2 & 4.1 & 4.2 & \\
\hline $\mathrm{Ca}$ & 0.9 & 0.8 & 0.6 & 0.7 & 0.5 & 0.9 & 0.9 & 0.7 & 0.7 & 0.7 & \\
\hline $\mathrm{Mg}$ & 1.3 & 1.2 & 1.2 & 1.3 & 1.1 & 1.3 & 1.2 & 1.3 & 1.3 & 1.2 & \\
\hline \multicolumn{12}{|c|}{ Straw, $\mathrm{g} / \mathrm{kg}$} \\
\hline $\mathrm{N}$ & 6.1 & 4.3 & 6.2 & 7.0 & 5.7 & 5.1 & 4.8 & 6.1 & 6.4 & 7.3 & $* * *$ \\
\hline $\mathrm{P}$ & 2.5 & 1.5 & 0.5 & 0.4 & 1.8 & 1.9 & 2.2 & 0.5 & 0.5 & 0.4 & \\
\hline K & 12.2 & 14.1 & 19.1 & 19.4 & 12.2 & 13.2 & 14.5 & 21.4 & 20.1 & 16.2 & \\
\hline $\mathrm{Ca}$ & 2.6 & 3.0 & 3.9 & 4.4 & 2.9 & 3.1 & 2.5 & 3.9 & 4.1 & 4.6 & \\
\hline $\mathrm{Mg}$ & 1.8 & 1.8 & 2.9 & 3.2 & 1.9 & 1.8 & 1.7 & 2.9 & 2.9 & 3.3 & \\
\hline
\end{tabular}

to dry slowly. In the statistical treatments the first year results were omitted and the means and the significance were calculated only from the results of the other seven years (Table 4). The figures of Table 5 show the plant nutrient contents of the yields. The most important of these are, naturally, the nitrogen contents.

The nitrogen economy of the pots is illustrated by the following figures covering the entire eight year period ( $\mathrm{N}$ /pot):

\begin{tabular}{|c|c|c|c|c|c|c|c|c|c|}
\hline & Winter & storag & & & & Peat & ddition & & \\
\hline & $\mathrm{N}_{0}$ & & $\mathrm{~N}_{2}$ & & $\mathrm{~N}_{0}$ & & & $\mathrm{~N}_{2}$ & \\
\hline 0 & i & o & i & $\mathrm{p}_{0}$ & $\mathrm{p}_{i}$ & $\mathrm{p}_{3}$ & $\mathrm{p}_{0}$ & $\mathrm{p}_{1}$ & $\mathrm{p}_{3}$ \\
\hline 0.7 & 0.9 & 13.4 & 13.8 & 0.8 & 0.7 & 1.0 & 13.7 & 13.8 & 14.0 \\
\hline 0 & 0 & 16 & 16 & 0 & 0 & 0 & 16 & 16 & 16 \\
\hline-0.7 & +0.9 & -2.6 & -2.2 & +0.8 & +0.7 & +1.0 & -2.3 & -2.2 & -2.0 \\
\hline
\end{tabular}

If the total nitrogen in the peat is included, $\mathrm{p}_{1}=6.2$ and $\mathrm{p}_{3}=18.6 \mathrm{~g} / \mathrm{pot}$, the differences are as follows:

$$
\begin{array}{llllll}
0.8 & -5.5 & -17.6 & -2.3 & -8.4 & -20.6
\end{array}
$$


According to the above calculation, $12-14 \%$ of the fertilizer nitrogen was not utilized by the yields, in fact the amount may be even larger because the yields without nitrogen fertilization contained small amounts of nitrogen. The fate of the nitrogen not utilized by crops has not been discovered.

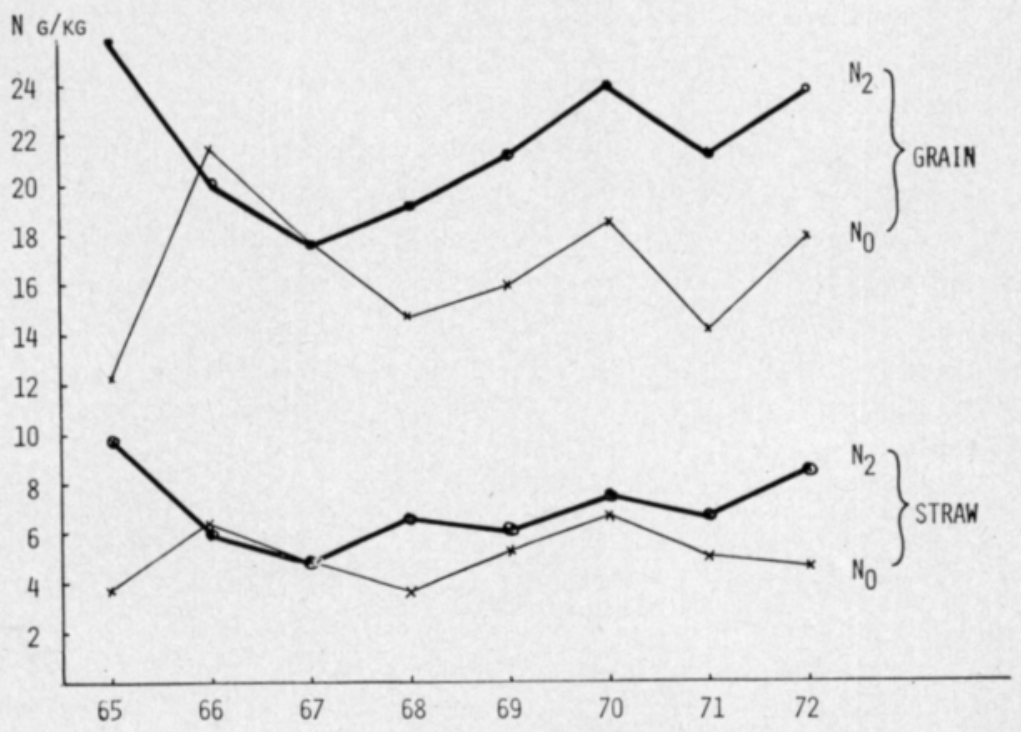

Figure 3. Nitrogen content of yields from different years.

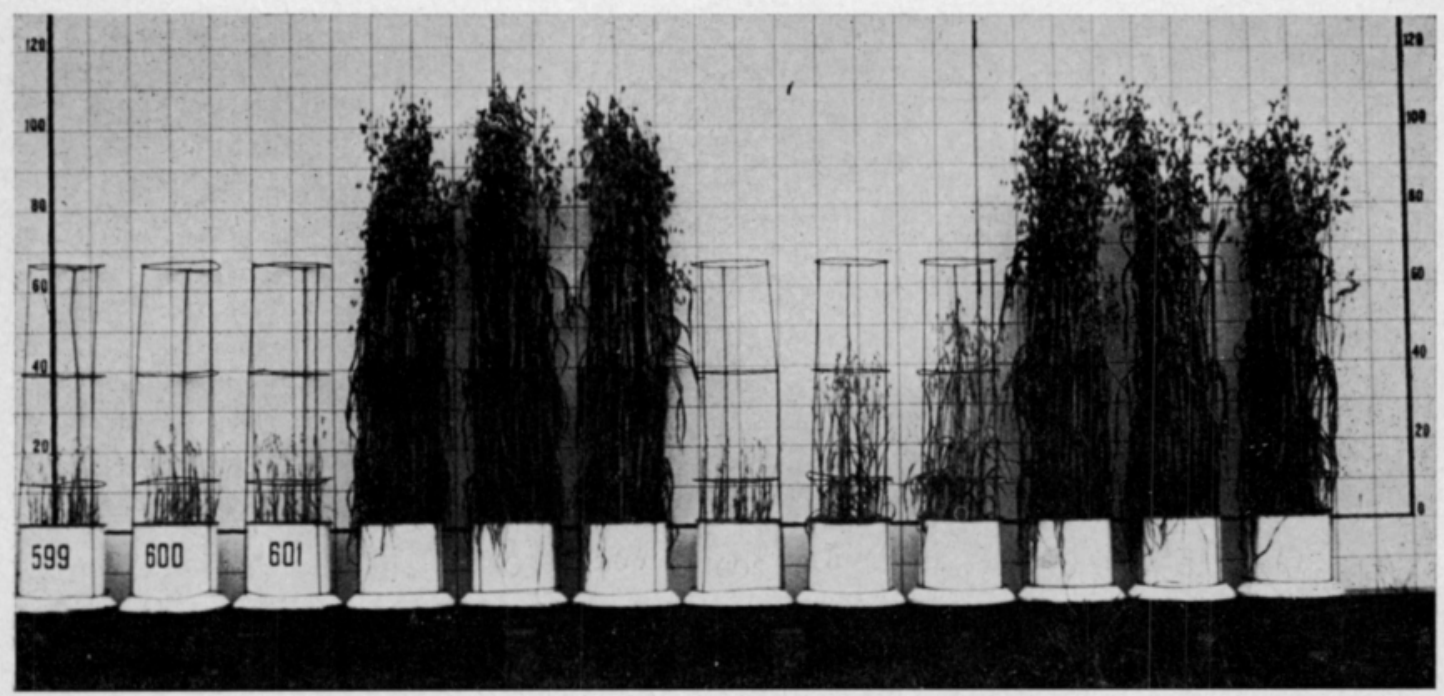

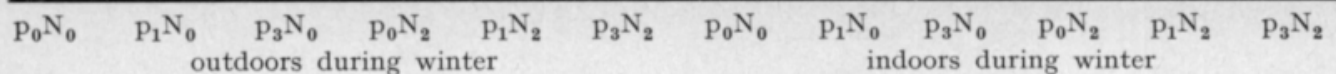

Figure 4. The experimental pots before harvest in 1967. The plant growth in the pots was very similar every year except in 1965 . 


\title{
Discussion
}

The effect of nitrogen fertilization shows that the experimental soil was suitable for the purpose. In this kind of soil even a slight nitrogen effect can be seen. The data clearly show that the nitrogen effect of the peat was very small. Raising the winter storage temperature, and promoting in this way decomposition, improved slightly the nitrogen effect of the peat. However, the field from which the peat had been taken, had been cultivated successfully without nitrogen fertilization. It is possible that the ratio of carbon and nitrogen was not low enough to enable the nitrogen to be released. This trend is likely to improve in time but could not yet be seen during the experimental period. It is possible that the close consistency of clay may slow down the decomposition of peat so efficiently that the nitrogen effect cannot take place. This may explain the poor results of farmyard manure used in clay soil (SALONEN and TAINIO 1956). According to present data, peat addition is not likely to produce a distinct plant nutrient effect. When peat addition has a positive effect in the field, it must be due to physical causes, most probably to improved soil moisture conditions.

\section{REFERENCES}

Allıson, F. E. 1973. Soil organic matter and its role in crop production. 637. New York.

Kurki, M., Lakanen, E., Mäkitie, O. Sillanpää, M. \& Vuorinen, J. 1965. Viljavuusanalyysien tulosten ilmoitustapa ja tulkinta. Ann. Agric. Fenn. 4: 145-153.

KйнйRI, J. 1976. Urea phosphate as nitrogen and phosphorus fertilizer. Ann. Agric. Fenn. 15: $163-167$.

Pessi, Y. \& PAULAMÄKI, E. 1964. Turpeen käytöstä savimaan maanparannusaineena. Suovilj.yhd. Vuosik. 1964: 26-34.

SALONEN, M. 1940. Kalkituksen vaikutuksista typen ja fosforihapon mobilisaatioon maassa. J. Scient. Agric. Soc. Finl. 12: 142-156.

Salonen, M. \& TArnio, A. 1956. Savimaan lannoitusta koskevia tutkimuksia. Valt. Maatal.koetoim. Julk. N:o 146.

TUorILA, P. 1945. Suomudan käytöstä maanparannusaineeksi kivennäismaille. Koetoim. ja Käyt. 2,1: 1-2.

TUORILA, P. 1946. Suomudan käytöstä kivennäismaiden maanparannusaineena. Koetoim. ja Käyt. 3,12: 1-2.

Ms received January 13, 1978.

\section{SELOSTUS}

\section{Suoturvelisäyksen typpivaikutuksesta humusköyhässä savimaassa}

\author{
Martti Salonen ja Jorma Kähäri \\ Maatalouden tutkimuskeskus, Maanviljelyskemian ja -fysiikan laitos, 01300 Vantaa 30
}

Kahdeksan vuotta kestäneessä astiakokeessa on tutkittu korkealaatuisen mutasuoturpeen typpivaikutusta humuksettomassa aitosavessa. Typpivaikutus todettiin niin pieneksi, ettei siihen kannata kiinnittää huomiota. Turvelisäyksen eräissä tapauksissa huomattavan vaikutuksen täytyy valtaosalta olla fysikaalista, lähinnä maan kosteussuhteiden paranemisesta johtuvaa. 